\title{
Synthesis, Characterization, Crystal Structure and Molecular Docking Studies of a S-methyldithiocarbazate Derivative: Bis[2-hydroxy- benzylidenehydrazono) (methylthio)methyl]disulfide
}

\author{
Winaki P. Sohtun, ${ }^{1}$ Arunachalam Kannan, ${ }^{2}$ K. Hari Krishna, ${ }^{3}$ \\ Dhandayutham Saravanan, ${ }^{2, \star}$ Muthuvel Suresh Kumar, ${ }^{3}$ and Marappan Velusamy ${ }^{1, *}$ \\ ${ }^{1}$ Department of Chemistry, North Eastern Hill University, Meghalaya 793022, India \\ ${ }^{2}$ Department of Chemistry, National College, Tiruchirappalli 620001, India \\ ${ }^{3}$ Centre for Bioinformatics, Pondicherry University, Pondicherry, 605014, India \\ *Corresponding author: E-mail: mvelusamy@gmail.com
}

Received: 16-02-2018

\begin{abstract}
The title compound bis[2-hydroxybenzylidenehydrazono)(methylthio)methyl]disulfide (1), an S-methyldithiocarbazate derivative with a disulfide bond has been synthesized by the condensation of 2-hydroxybenzaldehyde with S-methyldithiocarbazate. It has been characterized by elemental analyses, ${ }^{1} \mathrm{H},{ }^{13} \mathrm{C}$ NMR and FT-IR spectroscopy and mass spectrometry. The single crystal $\mathrm{X}$-ray structure shows that the compound exists in a tautomeric thione form with the dithiocarbazate fragment adopting an $E E$ configuration with respect to the $\mathrm{C}=\mathrm{N}$ bond of the benzylidene moiety. The thermal behaviour of the compound has been studied using thermogravimetric analysis (TGA). The molecular geometry of the compound in the ground state has been optimized using density functional theory (DFT/B3LYP) method with the 6-311++G(d,p) basis sets. Molecular docking of the compound with human carbonic anhydrase II has been performed to probe the nature of interaction.
\end{abstract}

Keywords: S-methyldithiocarbazate; TGA; Single crystal; Disulphide; Docking studies

\section{Introduction}

Disulfide compounds are widely distributed in natural bioactive components and show a wide range of potential pharmaceutical applications, such as stabilization and folding of proteins in biological systems. ${ }^{1}$ Organic compounds containing S-S bonds play an important role as an intermediate and as protecting groups in organic synthesis. ${ }^{2,3}$ Numerous strategies and reagents have been developed for the synthesis of disulfide bonds including metal based catalytic oxidation, 2,3-dichloro-5,6-dicyanobenzoquinone (DDQ) and peroxides. ${ }^{4-6}$ Currently, the synthesis and characterization of dithiocarbazate based Schiff bases are of great interest because of its potential application in biochemical and pharmacological applications. ${ }^{7-9}$ Schiff bases with carbazate moieties act as strong chelators and can form stable coordination complexes with a variety of metal ions. ${ }^{10,11}$ Due to easy preparation and structural va- rieties, they have been widely used as chelating ligands in the synthesis of a large variety of metal complexes. ${ }^{12,13}$ Metal complexes derived from dithiocarbazate ligands have been studied not only because of their exciting coordination chemistry, but also their prominent biological activities. ${ }^{14,15}$ These types of Schiff bases facilitate coordination metal ions with different oxidation states through the hard nitrogen and soft sulphur donors. The majority of previous studies were based on Schiff bases of thiosemicarbazones with tridentate N,N,S donor atoms, ${ }^{16-18}$ and only a few reports have been made using Schiff bases of dithiocarbazate derived from S-alkyl moiety. In biological systems, dithiocarbazates are extensively used as inhibitors of enzymes and for the treatment of cancer. ${ }^{19,20}$ In early studies, Bernhardt and co-workers synthesized a series of dithiocarbazate based ligands and their iron(II) complexes and studied their antiproliferative activities. ${ }^{21-23}$ Recently, Crouse et al. reported copper(II) complexes of a series of 
dithiocarbazate Schiff base and correlated their structures and their antibacterial activity. ${ }^{24}$ In this work, the Schiff base bis[2-hydroxybenzylidenehydrazono)-(methylthio) methyl]disulfide has been synthesized and characterized by elemental analyses and ${ }^{1} \mathrm{H}$ and ${ }^{13} \mathrm{C}$ NMR, FT-IR and mass spectrometry. The single crystal X-ray structure of the compound has been determined to assess the conformation of the molecule. The molecular docking of the compound with human carbonic anhydrase II has been also studied to understand the nature of interaction between them.

\section{Experimental}

\section{1. Materials and Physical Measurements}

Solvents were dried and distilled by standard methods before use. Reagents were purchased from commercial suppliers and used without further purification. S-methyldithiocarbazate was prepared according to the published procedure. ${ }^{25}{ }^{1} \mathrm{H}$ and ${ }^{13} \mathrm{C}$ NMR spectra were recorded on a Bruker AVANCE II $400 \mathrm{MHz}$ NMR spectrometer. IR spectra were recorded using Perkin-Elmer 983 model FT-IR spectrophotometer with compounds being dispersed as $\mathrm{KBr}$ discs. The electronic spectra were recorded on an $\mathrm{Ag}$ ilent-8453 diode array spectrophotometer. Mass spectrometry was performed on a Thermo LC-MS spectrometer.

\section{2. Synthesis of Compound 1}

A solution of S-methyldithiocarbazate $(1.22 \mathrm{~g}, 10$ $\mathrm{mmol})$ in ethanol $(20 \mathrm{~mL})$ was added to a stirred solution of 2-hydroxybenzaldehyde $(1.22 \mathrm{~g}, 10 \mathrm{mmol})$ in ethanol $(20 \mathrm{~mL})$. The mixture was stirred for $20 \mathrm{~min}$ and refluxed for $12 \mathrm{~h}$. The reaction mixture was then cooled to room temperature and the solid obtained was filtered off, washed several times with cold ethanol and dried under vacuum. Yield: $68 \%$. The above solid was dissolved in ethanol and refluxed under oxygen atmosphere for $24 \mathrm{~h}$. After cooling the solution at room temperature, the title compound in the form of brown needles was obtained. ${ }^{1} \mathrm{H}$ NMR (DMSO- $\left.d_{6}\right), \delta(\mathrm{ppm}) 2.43\left(\mathrm{~s}, 6 \mathrm{H}, \mathrm{S}-\mathrm{CH}_{3}\right), 6.92-6.87(4 \mathrm{H}, \mathrm{t}, J=$ $10 \mathrm{~Hz}), 7.34-7.31(2 \mathrm{H}, \mathrm{t}, J=6.0 \mathrm{~Hz}), 7.68-7.66(2 \mathrm{H}, \mathrm{Ar}, \mathrm{d}$, $J=8.0 \mathrm{~Hz}), 8.74(2 \mathrm{H}, \mathrm{s}, \mathrm{CH}=\mathrm{N}), 10.50(2 \mathrm{H}, \mathrm{s}, \mathrm{Ar}-\mathrm{OH}) .{ }^{13} \mathrm{C}$ NMR (DMSO- $\left.d_{6}\right), \delta(\mathrm{ppm}): 17.3\left(\mathrm{~S}-\mathrm{CH}_{3}\right), 116.9,119.6$ (C-C=N, Ar), 120.1, 127.7, $132.7(4 \mathrm{CH}, \mathrm{Ar}), 145.0$ $(\mathrm{HC}=\mathrm{N}), 157.7(\mathrm{C}-\mathrm{S}), 197.7(\mathrm{C}-\mathrm{O})$. ESI-MS $(\mathrm{m} / \mathrm{z}): 450.62$. UV-vis, $\lambda_{\mathrm{abs}}, \mathrm{nm}\left(\varepsilon, \mathrm{M}^{-1} \mathrm{~cm}^{-1}\right): 350$ (54858), 315 (59137), 300 (58055). Anal. found (calcd) for $\mathrm{C}_{18} \mathrm{H}_{18} \mathrm{~N}_{4} \mathrm{O}_{2} \mathrm{~S}_{4}$ : C, 47.82 (47.98); H, 4.12 (4.03); N, 12.49 (12.43).

\section{3. Single-crystal X-ray Studies}

A single-crystal for X-ray diffraction study was grown by slow evaporation of ethanol solution of $\mathbf{1}$ at room temperature. A suitable crystal was mounted on glass fiber for data collection. Data was collected on an Oxford Diffraction Xcalibur Eos Gemini diffractometer. Crystal data were collected at ambient temperature using graphite-monochromated Mo-Ka radiation $(\lambda=0.71073$ $\AA$ ). The data were solved using direct methods with SHELXS and refined using SHELXL-2013. ${ }^{26}$ The graphics interface package used was PLATON, and the figures were generated using the ORTEP 3.07 generation package. ${ }^{27}$ The positions of all atoms were obtained by direct methods. Non-hydrogen atoms were refined anisotropically. The hydrogen atoms were placed in calculated positions, constrained to ride on their parent atom with group $U_{\text {iso }}$ values assigned, $U_{\text {iso }}(\mathrm{H})=1.2 U_{\text {eq }}$ for aromatic carbons and $1.5 U_{\text {eq }}$ for methyl atoms. The crystallographic data and details of data collection for $\mathbf{1}$ are given in Table 1.

\section{4. Density Functional Theory Calculations}

One of the goals of computational chemistry is to understand the chemical reactivity and to predict the outcome of molecular interactions. Density functional theory (DFT) method has emerged as a powerful tool in studying molecular structure. Among the numerous available DFT methods, we have selected the B3LYP functional which combines the Becke's three-parameter exchange functional (B3) with the Lee-Yang-Parr correlation functional (LYP) with $6-311++\mathrm{G}(\mathrm{d}, \mathrm{p})$ basis set calculations ${ }^{28-30}$ were used for predicting the frontier orbitals (HOMO, LUMO) of the title compound. All DFT calculations were carried out using the Gaussian 09 program package. ${ }^{31} \mathrm{HOMO}-\mathrm{LUMO}$ values are the reliable estimates of reducing and oxidizing properties of the molecules and play an important role in stabilizing the interactions with the receptor. ${ }^{32,33}$

\section{5. Molecular Docking and Simulation Studies}

The biological importance of the synthesized ligand is assessed by performing the docking studies using the Schrödinger Glide software. ${ }^{34}$ The retrieved pdb file was prepared using the protein preparation wizard ${ }^{35}$ by removing the water molecules and ligands and the pdb was optimized by assigning the hydrogens, missing atoms, bonds and charges to the atoms. Ligand preparation including the generation of various tautomers, assigning bond orders, ring conformations and stereo chemistries of the ligand were carried out using the LigPrep. All the conformations generated were further minimized using OPLS2005 force field prior to docking study. A receptor grid was generated around the protein active site by selecting the active residues (Gln 92, Thr 199, Zn) with a size of $15 \AA$ using receptor grid generation. The docking calculations were performed using Extra Precision (XP) mode using the Ligand 
Docking and the Glide docking score was used to determine the best docked structure from the output.

MD simulations were performed using the GROMACS 5.0.6 version (www.gromacs.org) ${ }^{36}$ using the GROMOS 53a6 force field. ${ }^{37}$ PRODRG server ${ }^{38}$ was used to generate the topology files for the ligand. The protein was solvated by SPC (Single Point Charge) ${ }^{39}$ water molecules and the systems were neutralized using two $\mathrm{Cl}^{-}$counter ions. Periodic boundary conditions were implemented in all directions, using a simulation cell with a distance minimum of $1.0 \mathrm{~nm}$ from the protein. Electrostatic interactions were computed using the particle mesh Ewald $(\mathrm{PME})^{40}$ simulation method with a $1 \mathrm{~nm}$ short-range electrostatic cut-off. The short-range cut-off used for van der Waals interactions during the simulation was also $1 \mathrm{~nm}$. For the temperature coupling, the solvated structure was divided into two groups (protein and non-protein) using velocity rescaling with a stochastic term. The isotropic pressure coupling was employed in the MD simulation by using the Parrinello-Rahman method ${ }^{41}$ with a compressibility of $4.5 \cdot 10^{-5} \mathrm{bar}^{-1}$. During the simulation, constraints were deployed in all bands using the LINC algorithm ${ }^{42}$ with parameters LINC-order of 4 . First, each system was energy-minimized for 5,000 steps each using steepest-decent and conjugate gradient algorithms; subsequently, the solvent, and ions were equilibrated for $100 \mathrm{ps}$ in constant volume (NVT) and constant pressure (NPT) ensembles, respectively, while the substrates and cofactors of the protein were restrained harmonically using a force constant of $1000 \mathrm{~kJ} \mathrm{~mol}^{-1} \mathrm{~nm}^{-2}$. Finally, the two systems were performed for $5 \mathrm{~ns} \mathrm{MD}$ simulations after removing all the restraints and all the trajectories were stored every $0.002 \mathrm{ps}$ for further analysis. The binding free energies of the ligand were calculated using the g_mmpbsa program for the last $1 \mathrm{~ns}$ with a reference frame from every $50 \mathrm{ps}$.

\section{Results and Discussion}

The disulfide Schiff base was prepared and isolated in good yield which is characterized by spectral and single-crystal X-ray studies. The thermal property of the com- pound was determined by TGA analysis. DFT calculation and molecular docking studies were carried out by Gaussian 09 program package and Schrödinger Glide software respectively.

\section{1. Synthesis and Characterization}

The Schiff base containing a disulfide 1 has been prepared by aerial oxidation of $N^{\prime}$-(2-hydroxybenzylidene)hydrazinecarbodithioic acid methyl ester in ethanol at reflux temperature (Scheme 1). It was isolated as a pale yellow shiny crystalline solid. It is non-hygroscopic, air-stable and is highly soluble in common organic solvents. The compound was purified by recrystallization from ethanol solution and fully characterized by IR, ${ }^{1} \mathrm{H}$ and ${ }^{13} \mathrm{C}$ NMR, mass spectrometry, and electronic spectroscopy. The single-crystal X-ray structure of the compound has been determined.

\section{2. Spectral Studies of the Complex}

The ${ }^{1} \mathrm{H}$ NMR spectrum of compound 1 in DMSO- $d_{6}$ shows two signals at $\delta 10.5$ and $8.74 \mathrm{ppm}$ due the phenolic $\mathrm{OH}$ and azomethine $(-\mathrm{CH}=\mathrm{N}-)$ protons respectively. The $\mathrm{S}$-methyl $\left(-\mathrm{S}_{-} \mathrm{CH}_{3}\right)$ protons are observed at $\delta 2.43 \mathrm{ppm}$. The aromatic protons appear as multiplet in the region of $\delta$ $6.87-7.68 \mathrm{ppm}$. The ${ }^{13} \mathrm{C}$ NMR spectrum of 1 shows signals at $\delta 145.0,157.7$ and $197.7 \mathrm{ppm}$ due to the $\mathrm{C}=\mathrm{N}, \mathrm{C}-\mathrm{S}$ and $\mathrm{C}-\mathrm{O}$ (phenolic) carbons respectively. The $\mathrm{S}-\mathrm{CH}_{3}$ carbon is observed at $17.3 \mathrm{ppm}$. The phenyl ring carbons appear at $\delta$ $116.9,120.1,127.7,132.7$ ppm. ${ }^{43-45}$ The electronic absorption spectra of the compound have been recorded in acetonitrile and the corresponding spectrum was displayed in Figure 1. The compound showed three intense bands at 300,315 and $350 \mathrm{~nm}$ that can be assigned to $\pi \rightarrow \pi^{*}, \sigma \rightarrow \sigma^{*}$ transitions of the aromatic rings of benzene and $n \rightarrow \pi^{*}$ transitions of the azomethine chromophores respectively. ${ }^{46}$ In the IR spectrum, two prominent vibrational bands located at 3110 and $1620 \mathrm{~cm}^{-1}$ are characteristics of the $\mathrm{OH}$ and $\mathrm{C}=\mathrm{N}$ stretch, respectively. The peak obtained at 1033 $\mathrm{cm}^{-1}$ and $512 \mathrm{~cm}^{-1}$ were attributed to N-N and S-S stretching vibrations.
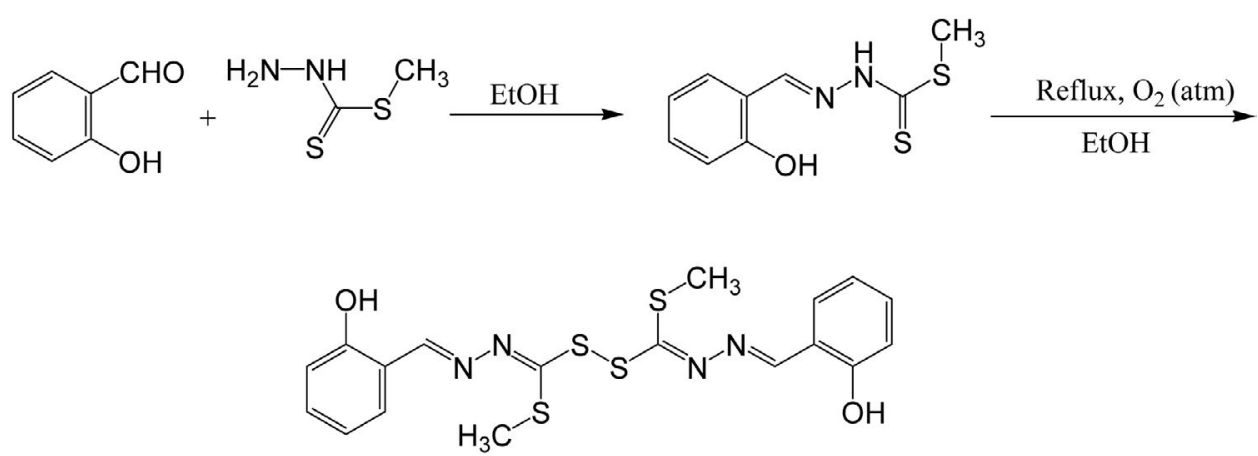

Scheme 1. Synthesis of the compound 1 


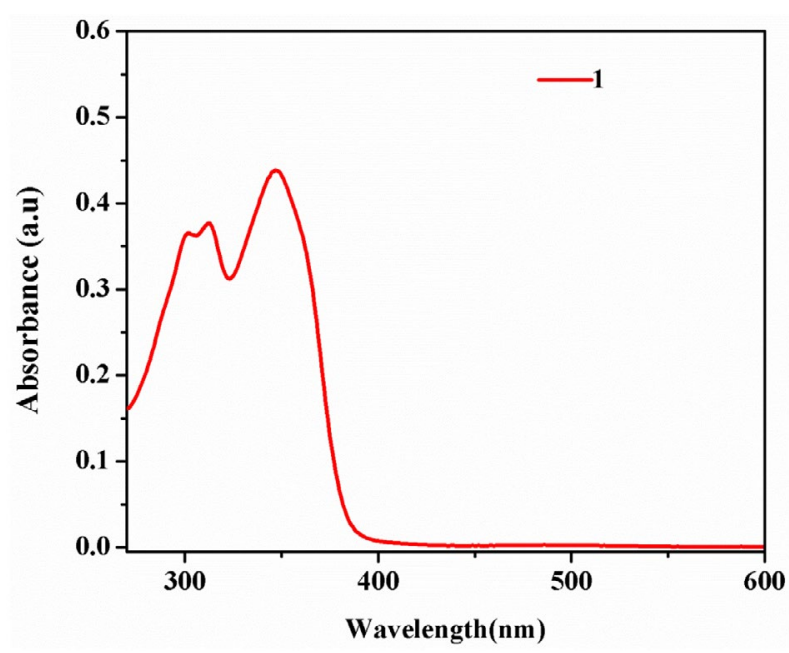

Figure 1. Electronic absorption spectra of $\mathbf{1}$ in acetonitrile

The IR spectrum of $\mathbf{1}$ does not display $v(\mathrm{~S}-\mathrm{H})$ at ca. $2570 \mathrm{~cm}^{-1}$ indicating that in the solid-state they remain in the thione form. ${ }^{47,48}$ The IR and NMR spectral properties are closely related to those of similar type of disulfide compounds reported already. ${ }^{49}$

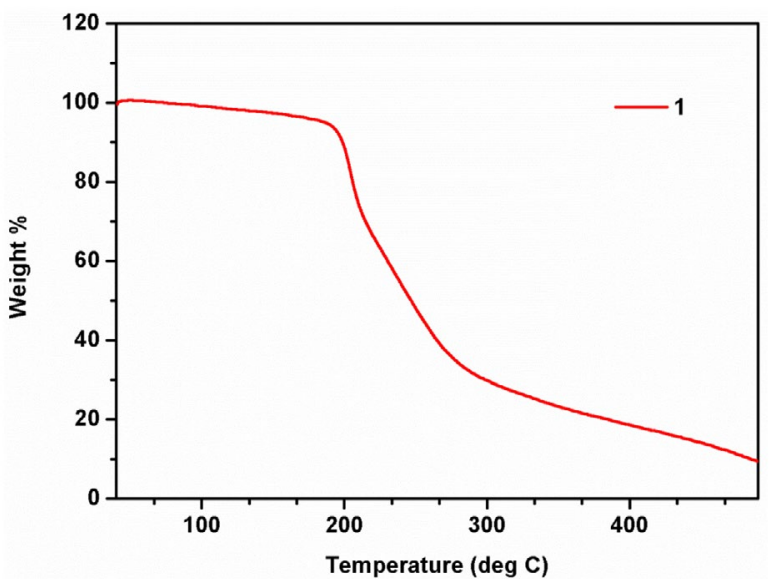

Figure 2. TGA curve for compound 1.

\section{3. Thermogravimetric Analysis (TGA)}

Thermal properties of the compound $\mathbf{1}$ was evaluated using TGA at a heating rate of $10^{\circ} \mathrm{C} / \mathrm{min}$ under nitrogen atmosphere with temperature range of $30-900{ }^{\circ} \mathrm{C}$ (Figure 2). The thermogram shows that there was no mass loss occurring below $100{ }^{\circ} \mathrm{C}$ and it was confirmed that the sample does not contain any solvent. Also, the degradation process of 1 starts at around $190^{\circ} \mathrm{C}$.

\section{4. Single-crystal X-ray Structure Analysis}

The single crystal of compound $\mathbf{1}$ was obtained by slow evaporation in an ethanol solution at room temperature. The molecular structure of $\mathbf{1}$ is shown in Figure 3 with displacement ellipsoids plotted at 50\% probability level. Compound 1 crystallizes as monoclinic crystal system in $P 2{ }_{1} / c$ space group, unit cell parameters $a=12.4489$ (8) $\AA, b=14.0742$ (9) $\AA$, $c=12.0688$ (8) $\AA$, $\alpha=90^{\circ}, \beta=$ $93.403^{\circ}$ and $\gamma=90^{\circ}$. Table S1 shows the selected bond

Table 1. Crystal data for compound 1.

\begin{tabular}{ll}
\hline Empirical formula & $\mathrm{C}_{18} \mathrm{H}_{18} \mathrm{~N}_{4} \mathrm{O}_{2} \mathrm{~S}_{4}$ \\
Formula weight & 450.60 \\
$T(\mathrm{~K})$ & $293(2)$ \\
Crystal system & Monoclinic \\
Space group & $P 2_{1} / c$ \\
$a(\AA)$ & $12.4489(8)$ \\
$b(\AA)$ & $14.0742(9)$ \\
$c(\AA)$ & $12.0688(8)$ \\
$\alpha\left(^{\circ}\right)$ & 90 \\
$\beta\left(^{\circ}\right)$ & $93.403(5)$ \\
$\gamma\left({ }^{\circ}\right)$ & 90 \\
$V\left(\AA^{3}\right)$ & $2110.8(2)$ \\
$Z$ & 4 \\
$D_{\mathrm{c}}\left(\mathrm{g} \mathrm{cm}^{-3}\right)$ & 1.418 \\
$\mu\left(\mathrm{mm}^{-1}\right)$ & 0.935 \\
$F(000)$ & 936 \\
Goof on $F^{2}$ & 1.017 \\
$R$ indices $[\mathrm{I}>2 \sigma(\mathrm{I})]$ & $R_{1}=0.0456, w R_{2}=0.1134$ \\
$R$ indices $($ all data $)$ & $R_{1}=0.0718, w R_{2}=0.0999$ \\
\hline
\end{tabular}

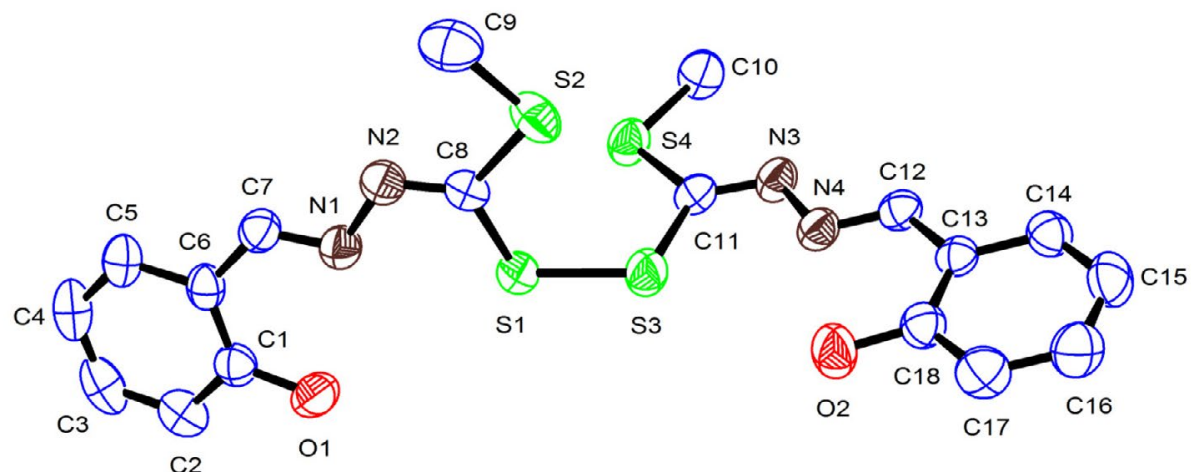

Figure 3. ORTEP diagram and atom labelling scheme for compound 1. Ellipsoids are plotted at $50 \%$ probability level. Hydrogen atoms are omitted for clarity. 
lengths and angles of $\mathbf{1}$. The bond lengths and angles are within the normal ranges and are comparable to those in related structures. ${ }^{50-52}$ The molecule adopts an $E E$ conformation with respect to the $\mathrm{C}=\mathrm{N}$ bond of the benzylidene moiety. The $\beta$-nitrogen and the thioether sulphur are trans located with respect to the $\mathrm{C} 11-\mathrm{N} 3$ and $\mathrm{C} 8-\mathrm{N} 2$ bond. The planarity of the molecule is stabilized by a strong intramo-

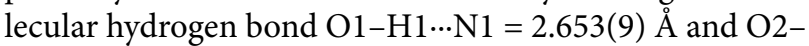
$\mathrm{H} 2 \cdots \mathrm{N} 4=2.631(5) \AA$. . The hydroxyphenyl moiety, which consists of C1-C7, N1, N2, C8 and C12-C18, N3, N4, C11, is nearly perpendicular to the disulfide plane $\mathrm{S} 1-\mathrm{S} 3-\mathrm{C} 11=$ $105.80(8)^{\circ}$ and S1-S3-C8 $=104.63(8)^{\circ}$. However, the observed S-S (2.039 $\AA), \mathrm{N}-\mathrm{N}(1.408 \AA), \mathrm{C}-\mathrm{N}(1.280 \AA)$ bond distances and S-C-N $\left(120.80^{\circ}\right)$, S-S-C $\left(104.63^{\circ}\right)$ bond angles are in the range of those reported for other closely related disulfide compounds, particularly, $S, S^{\prime}$-bis(2-hydroxybenzylidenehydrazono(phenyl)methyl)disulfide, (S-S, $2.050 \AA$; N-N, $1.406 \AA$; $-\mathrm{N}, 1.279 \AA) .{ }^{53}$

\section{5. Theoretical Results}

The ground state energy of compound $\mathbf{1}$ is calculated as $-7.3421 \times 10^{4} \mathrm{eV}$ by density functional theory (DFT) methods using B3LYP/6-31G(d,p) level. The Highest Occupied Molecular Orbital (HOMO) localized on half of the molecule that is from benzene ring to one of the sulfur atom in disulfide linkage. The Lowest Unoccupied Molecular Orbital (LUMO) localized on throughout the molecule.

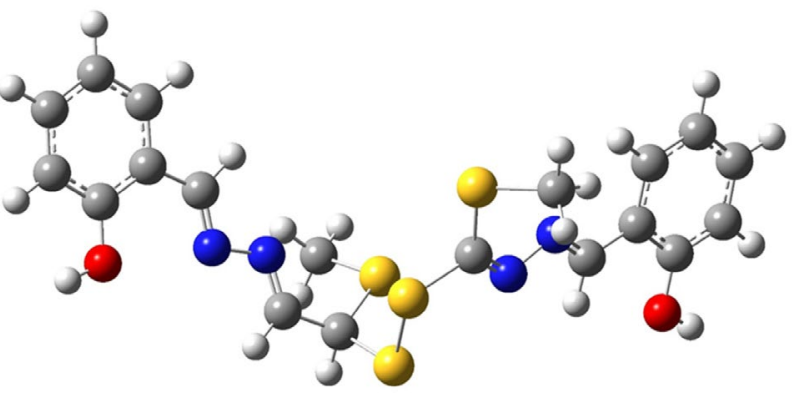

Figure 4. Ground state optimized structure of compound $1 \mathrm{calcu}-$ lated by DFT using B3LYP/6-31G (d, p) level.

The calculated bond lengths and bond angles are similar to that of crystal structure (Figure 4). The excited state calculation also been carried out by Time Dependent-DFT (TDDFT) methods. The energies of HOMO and LUMO are -5.7007 and $-1.6296 \mathrm{eV}$ and its energy gap is $4.0711 \mathrm{eV}$.

The wavelength corresponding to $4.0711 \mathrm{eV}$ is 304.54 $\mathrm{nm}$ and which can be correlated to band at $300 \mathrm{~nm}$ obtained from UV-vis spectral study. Along with this transition, it is found that there are three more excited state populated. The excitation energy of the excited state 1 is 3.34 $\mathrm{eV}$ with corresponding wavelength of $370.69 \mathrm{~nm}$ and the originated transitions are calculated as HOMO-3 to LUMO, HOMO- 3 to LUMO+1 and HOMO- 4 to LUMO. The excitation energy of the excited state 2 is $3.38 \mathrm{eV}$ with corresponding wavelength of $366.72 \mathrm{~nm}$ and the originat-
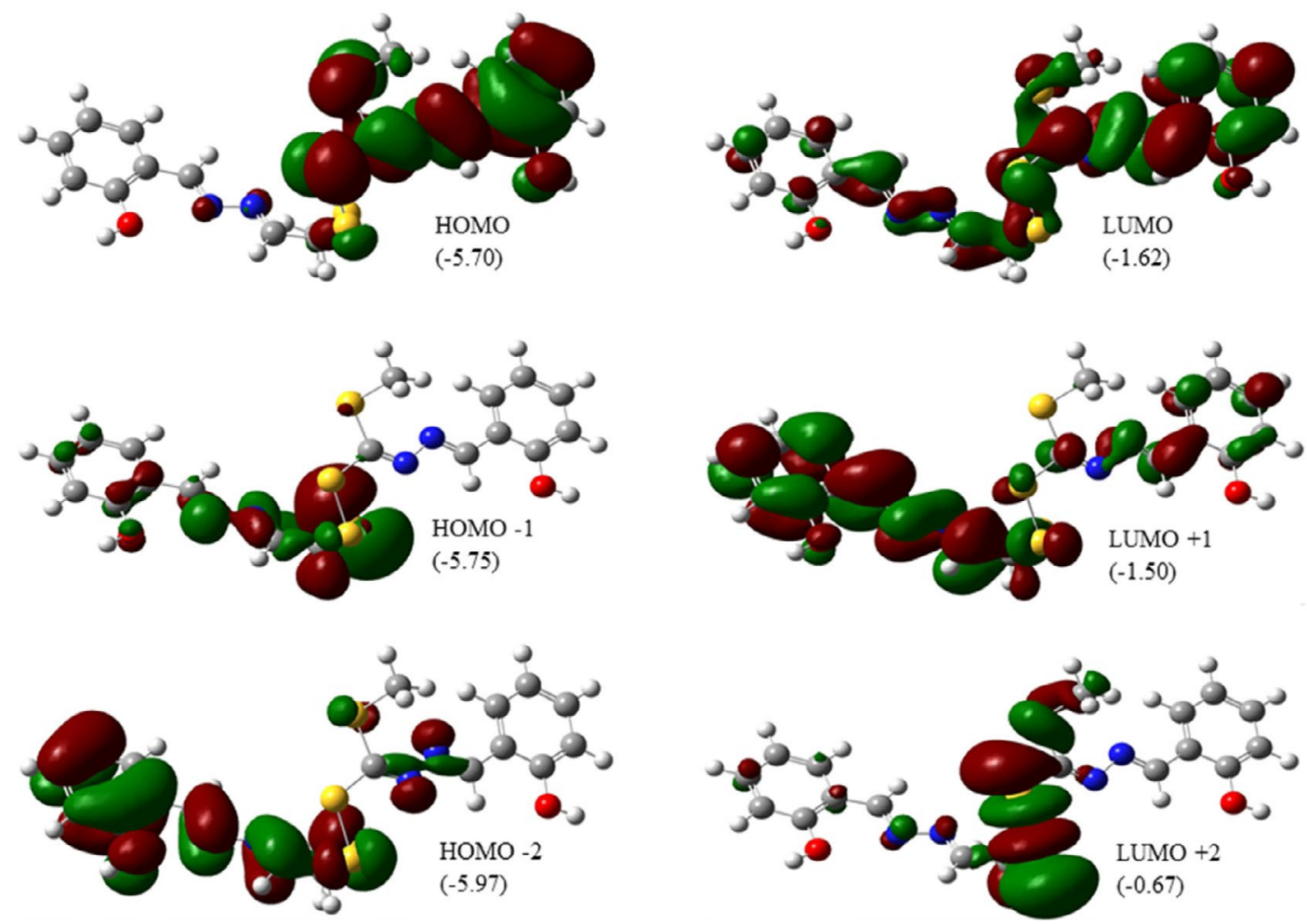

Figure 5. HOMO's and LUMO's of compound 1 calculated by TD-DFT using B3LYP/6-31G(d, p) level; the corresponding energies (in eV) are mentioned in parenthesis. 
ed transitions are calculated as HOMO-4 to LUMO, HOMO-4 to LUMO+1, HOMO-1 to LUMO, HOMO-1 to $\mathrm{LUMO}+1$ and $\mathrm{HOMO}$ to $\mathrm{LUMO}+1$. The excitation energy of the excited state 3 is $3.56 \mathrm{eV}$ with corresponding wavelength of $347.94 \mathrm{~nm}$ and the originated transitions are calculated as HOMO-4 to LUMO, HOMO-4 to LUMO+1 and HOMO-1 to LUMO (Figure 5). The calculated excitation energies are matched with the UV-vis experimental data. These computational results elucidate that both crystal structure and computationally calculated structure are similar in terms of bond lengths, bond angle and excitation energies.

\section{6. Molecular Docking Studies}

The pdb structure $3 \mathrm{~K} 34^{54}$ of human carbonic anhydrase II was used for the docking studies with retaining the Zn metal ion cofactor, which plays a key role in the protein catalytic mechanisms. The best docked complex selected has a Glide dock score of -6.8 which predicts a good inhibition of the carbonic anhydrase II. The docked complex is stabilized by the $\pi-\pi$ stacking of the phenol group of the ligand with the imidazole ring system of His 94 . Similarly, the second phenol group interacts with the Thr 200 by the side chain $\mathrm{H}$ bonding. The amine group of the ligand interacts with the backbone of the Pro 201 through $\mathrm{H}$ bond. The cofactor $\mathrm{Zn}$ metal ion involves in a non-bonded contacts with the two phenol ring systems. The ligand protein interaction was further stabilized by the non-bonded hydrophobic and polar interactions of the ligand with the surrounding residues. The binding mode of the ligand to the carbonic anhydrase is shown in Figure 6.
The trajectory file from the production run was analyzed for the stability of the ligand in the docked complex. The root mean square deviation (RMSD) graph of the protein shows stability at $0.3 \mathrm{~nm}$ after a time period of $2 \mathrm{~ns}$ whereas the ligand shows an altered $\mathrm{rms}$ values ranging $0.1-0.3 \mathrm{~nm}$ which shows the stability of the ligand at the docked site. The root mean square fluctuation (RMSF) of the protein residues shows stability with deviations lesser than $0.3 \mathrm{~nm}$. The docked ligand interacts with a single $\mathrm{H}$ bond with the protein, which increases to three bonds during the course of the simulation. Figure 7 illustrates the analysis in the graphical format.

Residues Trp 5, Asn 62, Asn 67, Gln 92 and Thr 199 form an $\mathrm{H}$ bond during the course of the simulation. The docked ligand has a binding energy of $-176.90 \mathrm{~kJ} / \mathrm{mol}$ as shown in the Table 2 with the protein, which shows that ligand can act as a potent inhibitor for the carbonic anhydrase II.

Table 2: The interaction values of the ligand with the protein showing the various contributing energy terms.

\begin{tabular}{lc}
\hline Energy terms & Energy values, kJ/mol \\
\hline Van der Waal energy & $-188.212 \pm 3.813$ \\
Electrostatic energy & $-2.394 \pm 0.934$ \\
Polar solvation energy & $67.500 \pm 3.575$ \\
SASA energy & $-19.387 \pm 0.276$ \\
SAV energy & $-120.072 \pm 3.200$ \\
WCA energy & $85.363 \pm 4.258$ \\
Binding energy & $-176.908 \pm 8.392$ \\
\hline
\end{tabular}

SASA: Solvent Accessible Surface Area; SAV: Solvent Accessible Volume; WCA: Weeks-Chandler-Andersen.

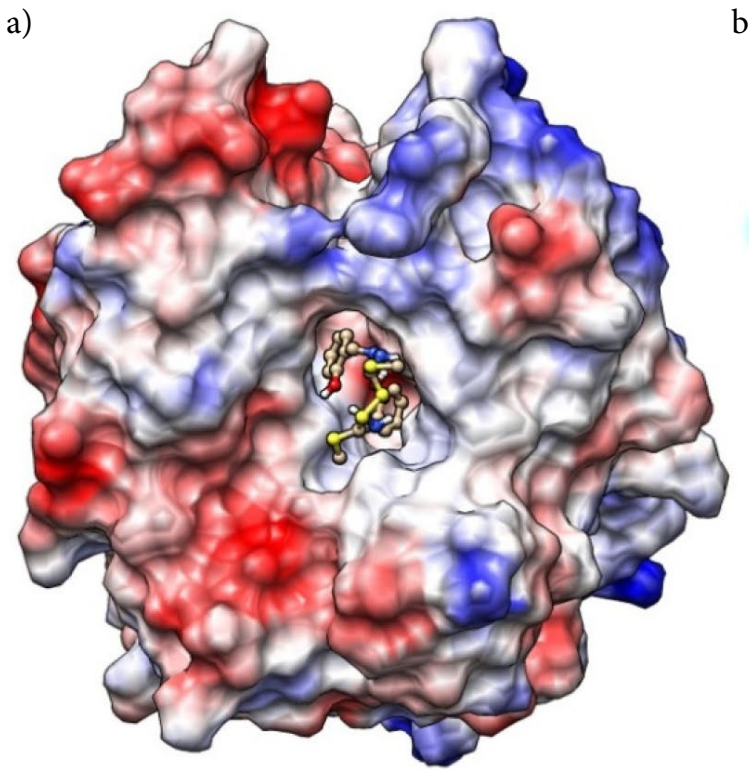

b)

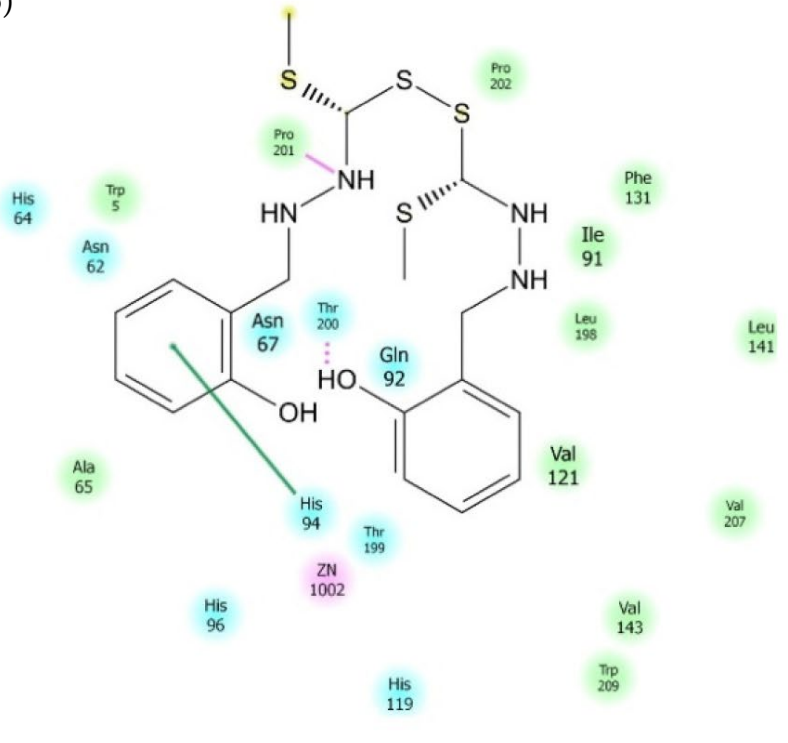

Figure 6. (a) Position of the docked ligand in the binding cavity of protein shown with electroscopic surface map; Red: high negative potential region, White: neutral region, Blue: positive potential region. (b) Ligand interacting residues with the protein in a $2 \mathrm{~d}$ map; Green: $\pi-\pi$ stacking bond, Red: Hydrogen bonds. The residues involved in the non-bonded interactions are shown as spheres. 


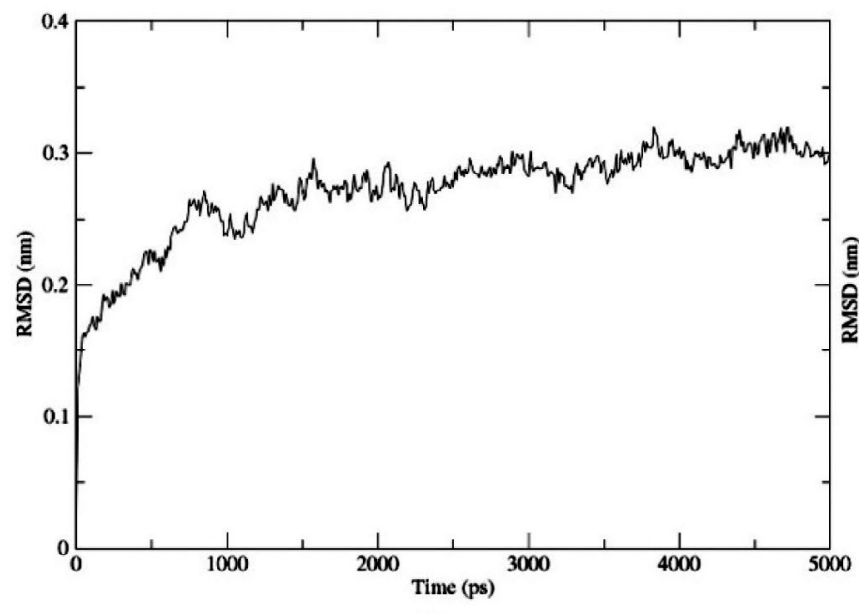

a)

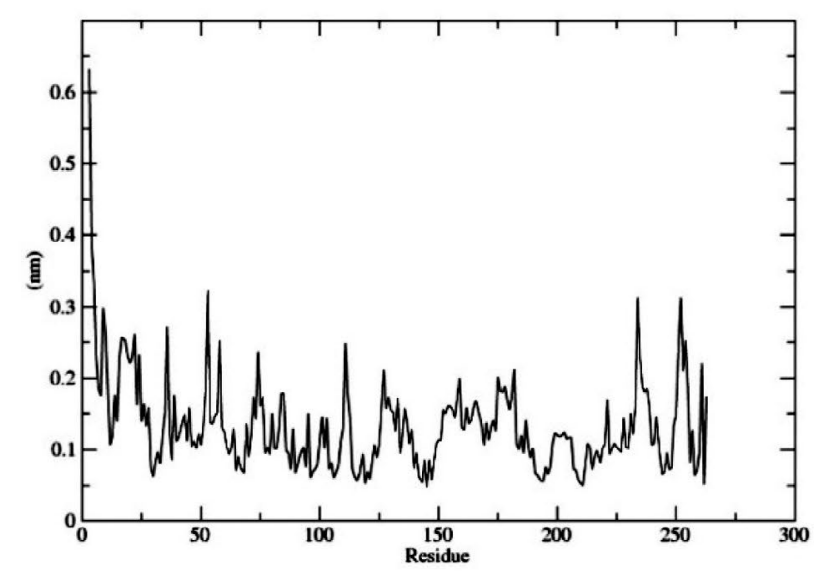

c)

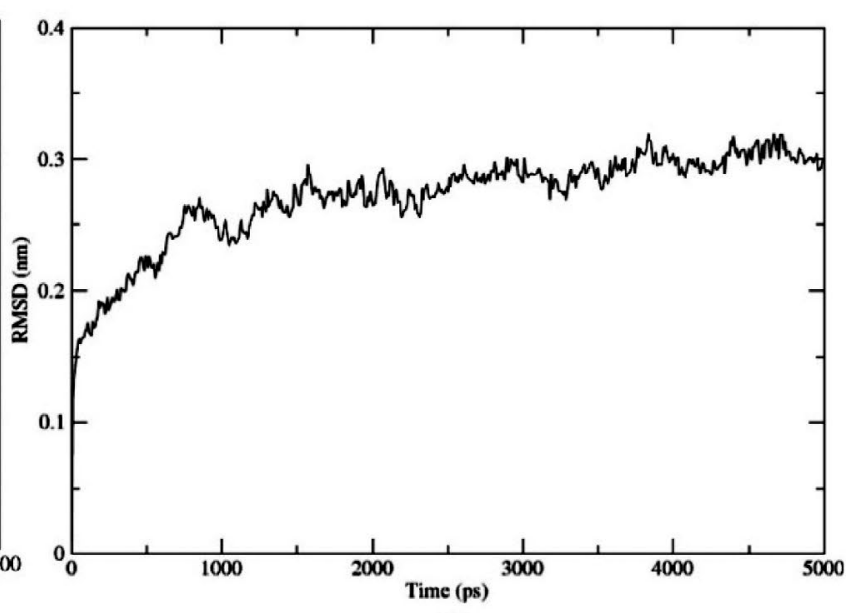

b)

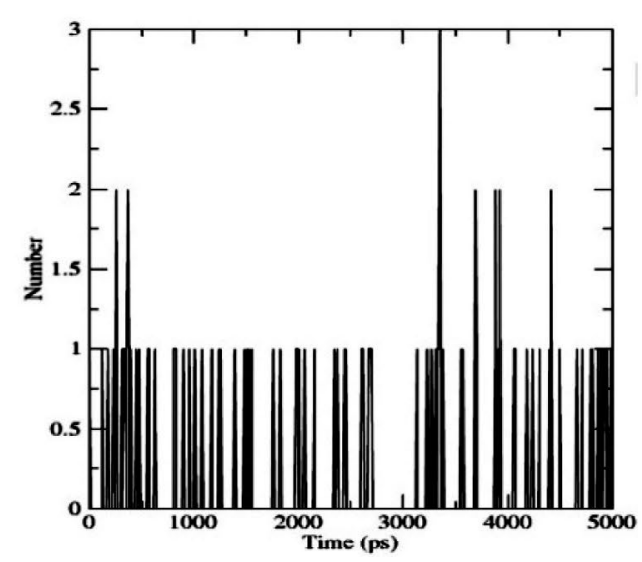

e)

Figure 7. (a) and (b) show the rmsd of the protein and the ligand from the trajectory file. (c) Shows the fluctuation of the protein residues in the course of the simulation. (d) Shows the number of $\mathrm{H}$ bonds between the ligand and the protein across the time.

\section{Conclusions}

In the present study the preparation of the novel compound bis[2-hydroxybenzylidenehydrazono)(methylthio)methyl]disulphide is reported. The compound has been characterized by UV-vis, IR, NMR, and mass spectrometry. It crystallizes in the monoclinic system with the centrosymmetric space group $P 2_{1} / c$. The single crystal $\mathrm{X}$-ray structure determination shows that the compound adopts an $E E$ conformation with respect to $\mathrm{C}=\mathrm{N}$ bond of the benzylidene moiety. The thermal behaviour of the compound has been studied using thermogravimetric analysis (TGA). Theoretical calculations have been performed with DFT/B3LYP/6-31++G(d,p) basis set. The electronic properties have been also calculated (TD-DFT) and compared with the experimental UV-Vis spectrum. The molecular docking studies reveal that the compound can act as a potent inhibitor of carbonic anhydrase II activity.

\section{Acknowledgements}

We thank DST-PURSE, NEHU-SAIF Shillong, India, for providing XRD and NMR spectral facilities. One of the authors M. V. express his thanks to UGC, MRP-MAJORCHEM 2013-5144, (69/2014 F. No. 10-11/12) for financial assistance in the form of a major sponsored project.

\section{References}

1. Y, Hidaka, S. Shimamoto, Biomole. Concepts 2013, 4, 597-604. DOI:10.1515/bmc-2013-0022

2. W, Ge, Y,Wei, Green Chem. 2012, 14, 2066-2070. DOI:10.1039/C2GC35337G

3. G, Saito, J. A. Swanson, K. D. Lee, Adv. Drug Deliv. Rev. 2003, 55, 199-215. DOI: 10.1016/S0169-409X(02)00179-5

4. Mandala B, Basu B, RSC Adv. 2014, 4, 13854-13881

DOI: $10.1039 / \mathrm{C} 3 \mathrm{RA} 45997 \mathrm{G}$ 
5. S, Harusawa, K, Yoshida, C, Kojima L, Araki T, Kurihara, Tetrahedron 2004, 60, 11911-11922.

DOI: $10.1016 /$ j.tet.2004.09.109

6. J. K, Vandavasi. W. P, Hu, C. Y, Chen J. J, Wang, Tetrahedron 2011, 67, 8895-8901. DOI:10.1016/j.tet.2011.09.071

7. M. L, Low. L, Maigre, M. I. M. Tahir, E. R. T. Tiekink, P. Dorlet, R. Guillot, T. B. Ravoof, R. Rosli J. M. Pages, C. Policar, N. Delsuc, K. A. Crouse, Eur. J. Med. Chem. 2016, 120, 1-12. DOI:10.1016/j.ejmech.2016.04.027

8. D. B. Lovejoy, D. M Sharp, N. Seebacher, P. Obeidy, T. Prichard, C. Stefani, M. T Basha, P. C. Sharpe, P. J Jansson, D. S. Kalinowski, P. V. Bernhardt, D. R. Richardson, J. Med. Chem. 2012, 55, 7230-7244. DOI:10.1021/jm300768u

9. P. Quach, E. Gutierrez, M. T Basha, D. S. Kalinowski, P. C. Sharpe, D. B. Lovejoy, P. V. Bernhardt, P. J. Jansson, D. R. Richardson, Mol. Pharmacol. 2012, 82, 105-114.

DOI: $10.1124 / \mathrm{mol} .112 .078964$

10. E. Zangrando, M. T. Islam, M. A. A. A. Islam, M. C. Sheikh, M. T. H. Tarafder, R. Miyatake, R. Zahan, M. A. Hossain, Inorg. Chim. Acta 2015, 427, 278-284.

DOI: $10.1016 /$ j.ica.2014.12.014

11. X.-Y. Qiu, C. Zhang, S. -Z. Li, G.-X. Cao, P. Qu, F.-Q. Zhang, J.-G. Ma, B. Zhai, Inorg. Chem. Commun. 2014, 46, 202-206. DOI:10.1016/j.inoche.2014.05.015

12. M. X. Li, L. Z. Zhang, C. L. Chen, J. Y. Niu, B. S. Ji, J. Inorg. Biochem. 2012, 106, 117-125.

DOI: $10.1016 /$ j.jinorgbio.2011.09.034

13. M. A. Ali, A. H. Mirza, H. J. H. A. Bakar, P. V. Bernhardt, Polyhedron 2011, 30, 556-564. DOI:10.1016/j.poly.2010.11.016

14. P. K. Sasmal, A. K. Patra, A. R. Chakravarty, J. Inorg. Biochem. 2008, 102, 1463-1472. DOI: 10.1016/j.jinorgbio.2007.12.031

15. M. A. Ali, R. J. Butcher, J. C. Bryan, Inorg. Chim. Acta 1999, 287, 8-13. DOI: 10.1016/S0020-1693(98)00384-3

16. N. Gokhale, S. Jain, M. Yadav, Curr. Top. Med. Chem. 2015, 15, 37-42. DOI:10.2174/1568026615666150112110211

17. B. M. Paterson, P. S. Donnelly, Chem. Soc. Rev. 2011, 40, 3005-3018. DOI:10.1039/C0CS00215A

18. T. S. Lobana, R. Sharma, G. Bawa, S. Khanna, Coord. Chem. Rev. 2009, 253, 977-1055. DOI: 10.1016/j.ccr.2008.07.004

19. M. L. Low, G. Paulus, P. Dorlet, R. Guillot, R. Rosli, N. Delsuc, K. A. Crouse, C. Policar, Biometals 2015, 28, 553-566. DOI:10.1007/s10534-015-9831-2

20. A. B. Beshir, S. K. Guchhait, J. A. Gasco'n, G. Fenteany, Bioorg. Med. Chem. Lett. 2008, 18, 498-504.

DOI:10.1016/j.bmcl.2007.11.099

21. M. T. Basha, D. Chartres, N. Pantarat, M. A. Ali, A. H. Mirza, D. S. Kalinowski, D. R. Richardson, P. V. Bernhardt, Dalton Trans. 2012, 41, 6536-6548. DOI:10.1039/C2DT12387H

22. Z. A. Eisawi, C. Stefani, P. J. Jansson, A. Arvind, P. C. Sharpe, M. T. Basha, G. M. Iskander, N. Kumar, Z. Kovacevic, D. J. R. Lane, S. Sahni, P. V. Bernhardt, D. R. Richardson, D. S. Kalinowski, J. Med. Chem. 2016, 59, 294-312.

DOI: 10.1021 /acs.jmedchem.5b01399

23. C. Stefani, P. J. Jansson, E. Gutierrez, P. V. Bernhardt, D. R. Richardson D. S, J. Med. Chem. 2013, 56, 357-370.

DOI: $10.1021 / \mathrm{jm} 301691 \mathrm{~s}$
24. M. L. Low, L. Maigre, P. Dorlet, R. Guillot, J. M. Pagès, K. A. Crouse, C. Policar, N. Delsuc, Bioconjugate Chem. 2014, 25 , 2269-2284. DOI:10.1021/bc5004907

25. T. B. S. A. Ravoof, K. A. Crouse, M. I. M. Tahir, R. Rosli, D. J. Watkin, F. N. F. How, J. Chem. Crystallogr. 2011, 41, 491-495. DOI: $10.1007 /$ s10870-010-9907-3

26. G. Sheldrick, 2013. SHELXL2013. Program for Structure Refinement, University of Goettingen, Germany

27. M. N. Burnett, G. K. Johnson, 1996 ORTEP III, Report ORNL-6895, OAK Ridge National Laboratory; Tennessee, USA

28. A. D. Becke, J. Chem. Phys. 1993, 98, 5648-5652. DOI:10.1063/1.464913

29. C. Lee, W. Yang, R. C. Parr, Phys. Rev. 1988, B37, 785-789. DOI:10.1103/PhysRevB.37.785

30. J. P. Perdew, Y. Wang, Phys. Rev. B, 1986, 33, 8800-8802. DOI:10.1103/PhysRevB.33.8800

31. M. J. Frisch, G. W. Trucks, H. B. Schlegel, G. E. Scuseria, M. A. Robb, J. R. Cheeseman, G. Scalmani, V. Barone, B. Mennucci, G. A. Petersson, H. Nakatsuji, M. Caricato, X. Li, H. P. Hratchian, A. F. Izmaylov, J. Bloino, G. Zheng, J. L. Sonnenberg, M. Hada, M. Ehara, K. Toyota, R. Fukuda, J. Hasegawa, M. Ishida, T. Nakajima, Y. Honda, O. Kitao, H. Nakai, T. Vreven, Jr. J. A. Montgomery, J. E. Peralta, F. Ogliaro, M. J. Bearpark, J. Heyd, E. N. Brothers, K. N. Kudin, V. N. Staroverov, R. Kobayashi, J. Normand, K. Raghavachari, A. P. Rendell, J. C. Burant, S. S. Iyengar, J. Tomasi, M. Cossi, N. Rega, N. J. Millam, M. Klene, J. E. Knox, J. B. Cross, V. Bakken, C. Adamo, J. Jaramillo, R. Gomperts, R. E. Stratmann, O. Yazyev, A. J. Austin, R. Cammi, C. Pomelli, J. W. Ochterski, R. L. Martin, K. Morokuma, V. G. Zakrzewski, G. A. Voth, P. Salvador, J. J. Dannenberg, S. Dapprich, A. D. Daniels, Ö. Farkas, J. B. Foresman, J. V. Ortiz, J. Cioslowski, D. J. Fox, 2009, Gaussian 09.

32. A. D. Bochevarov, E. Harder, T. F. Hughes, J. R. Greenwood, D. A. Braden, D. M. Philipp, D. Rinaldo, M. D. Halls, J. Zhang, R. A. Friesner, A. Jaguar, Int. J. Quant. Chem. 2013,113, 21102142. DOI:10.1002/qua.24481

33. E. Eroglu, H. A. Türkmen, J. Mol. Graph Model. 2007, 26, 701-708. DOI:10.1016/j.jmgm.2007.03.015

34. R. A. Friesner, J. L. Banks, R. B. Murphy, T. A. Halgren, J. J. Klicic, D. T. Mainz, M. P. Repasky, E. H. Knoll, M. Shelley, J. K. Perry, D. E. Shaw, P. Francis, P. S. Shenkin, J. Med. Chem. 2004, 47, 1739-1749. DOI: 10.1021/jm0306430

35. G. M. Sastry, M. Adzhigirey, T. Day, R. Annabhimoju, W. Sherman, J. Comput. Aided Mol. Des. 2013, 27, 221-234.

DOI:10.1007/s10822-013-9644-8

36. S. Pronk, GROMACS 4.5, 2013, 29, 845.

37. C. Oostenbrink, A. Villa, A. E. Mark, V. W. F. Gunsteren, J. Comput. Chem. 2004, 25, 1656-1676.

DOI:10.1002/jcc.20090

38. A. W. Schuttelkopf, D. M. V. Aalten, Acta Cryst. 2004, D60, 1355-1363. DOI: $10.1107 /$ S0907444904011679

39. H. J. C. Berendsen, J. P. M. Postma, W. F. V. Gunsteren, J. Hermans, Interaction Models for Water in Relation to Protein Hydration, in Intermolecular Forces, Pullman B, Editor. Springer Netherlands. 1981, p. 331. 
40. T. Darden, D. York, L. Pedersen, J. Chem. Phys. 1993, 98, 10089-10092. DOI: 10.1063/1.464397

41. M. Parrinello, A. Rahman, J. Appl. Phys. 1981, 52, 7182-7190. DOI:10.1063/1.328693

42. B. Hess, B. Henk, H. J. C. Berendsen, J. G. E. M. Fraaije, J. Comput. Chem. 1997, 18, 1463-1472.

DOI:10.1002/(SICI)1096-987X(199709)18:12<1463:

:AID- JCC4>3.0.CO;2-H

43. M. A. A. A. Islam, M. T. H. Tarafder, M. C. Sheikh, M. A. Alam, E. Zangrando, Trans. Met. Chem. 2011, 36, 531-535. DOI:10.1007/s11243-011-9499-6

44. C. F. Wise, D. Liu, K. J. Mayer, P. M. Crossland, C. L. Hartley, W. R. A. McNamara, Dalton Trans. 2015, 44, 14265-14271. DOI:10.1039/C5DT02042E

45. M. A. Ali, A. H. Mirza, R. J. Butcher, K. A. Crouse, Trans. Met. Chem. 2006, 31, 79-87. DOI:10.1007/s11243-005-6305-3

46. K. Chew, M. T. H. Tarafder, K. A. Crouse, A. M. Ali, B. M. Yamin, H.-K. Fun, Polyhedron, 2004, 23, 1385-1392. DOI:10.1016/j.poly.2004.02.018

47. N. R. Pramanik, M. Chakraborty, D. Biswal, S. S. Mandal, S. Ghosh, S. Chakrabarti, W. S. Sheldrick, M. G. B. Drew, T. K. Mondal, D. Sarkar, Polyhedron, 2015, 85, 196-207.
DOI:10.1016/j.poly.2014.08.010

48. M. T. H. Tarafder, T.-J. Khoo, K. A. Crouse, A. M. Ali, B. M. Yamin, H.-K. Fun, Polyhedron, 2002, 21, 2691-2698.

DOI:10.1016/S0277-5387(02)01272-X

49. S. Kubota, H. K. Misra, M. Shibuya, Synthesis, 1982, 18, 776778. DOI:10.1055/s-1982-29941

50. M. Yazdanbakhsha, M. M. Heravib, R. Takjooa, W. Frank, Z. Anorg. Allg. Chem. 2008, 634, 972-976.

DOI:10.1002/zaac.200700521

51. M. A. F. A. Manan, K. A. Crouse, M. I. M. Tahir, R. Rosli, F. N.-F. How, D. J. Watkin, A. M. Z. Slawin, J. Chem. Crystallogr. 2004, 41, 1630-1641. DOI:10.1007/s10870-011-0151-2

52. A. H. Mirza, M. H. S. A. Hamid, S. Aripin, M. R. Karim, M. Arifuzzaman, M. A. Ali, P. V. Bernhardt, Polyhedron, 2014, 74, 16-23. DOI: $10.1016 /$ j.poly.2014.02.016

53. D. S. Kalinowski, P. C. Sharpe, P. V. Bernhardt, D. R. Richardson, J. Med. Chem. 2007, 50, 6212-6225.

DOI:10.1021/jm070839q

54. C. A. Behnke, I. L. Trong, J. W. Godden, E. A. Merritt, D. C. Teller, J. Bajorath, R. E. Stenkampa, Acta Cryst. 2010, D66, 616-267. DOI:10.1107/S0907444910006554

\section{Povzetek}

Spojino bis[2-hidroksibenzilidenhidrazono)(metiltio)metil]disulfid (1), ki je derivat S-metilditiokarbazata $\mathrm{z}$ disulfidno vezjo smo sintetizirali s kondenzacijo 2-hidroksibenzaldehida in S-metilditiokarbazata. Okarakterizirali smo jo $\mathrm{z}$ elementno analizo, ${ }^{1} \mathrm{H},{ }^{13} \mathrm{C}$ NMR in FT-IR spektroskopijo in masno spektrometrijo. Rentgenska struktura razkrije, da je spojina $\mathrm{v}$ tavtomerni obliki tiona $\mathrm{z}$ ditiokarbazatnim fragmentom $\mathrm{z} E E$ konfiguracijo glede na $\mathrm{C}=\mathrm{N}$ vez benzilidenske skupine. Termične lastnosti spojine smo proučili z termogravimetrično analizo (TGA). Geometrijo spojine v osnovnem stanju smo optimizirali z uporabo teorije gostotnostnega funkcionala (DFT/B3LYP) z uporabo 6-311++G(d,p) baznega seta. Molekularni docking spojine z človeško karbonsko anhidrazo II smo izvedli za določitev interakcij. 